\title{
An Uneasy Pleasure: Representing the Dangers of Skin-to-skin Contact in Eighteenth-century London 'The William Bynum Prize Essay'
}

\author{
SARA FERNANDES * \\ The University of Sydney, Camperdown, NSW, Australia 2006
}

\begin{abstract}
This article considers the social function of contagious disease as moderator of class relationships in England during the first half of the eighteenth century and takes into account the ways in which the 'communicability' of the plague, great pox (syphilis) and smallpox (variola) was used by authors to crystallise social interaction and tension along class lines. The essay begins by examining the representation of the plague, syphilis and smallpox in the medical tradition, before shifting its attention to the practice of maritime quarantine, as laid out by Richard Mead in his Short Discourse Concerning Pestilential Contagion (1720). By foregrounding medical writing on contagion through skin contact, I suggest that pornographic texts such as John Cleland's The Memoirs of a Woman of Pleasure (Fanny Hill) (1748) had an interventionist function. Cleland is often charged with sanitising the true horrors of sex work in this period. This article proposes that if we take the time to appreciate the way infectious cutaneous diseases were believed to operate and spread we can recognise the moments in which he not only alludes to disease but invokes it for structural and thematic purposes. In proposing this, I am challenging the dominant interpretation that the problematic realities of eighteenth-century prostitution, especially disease, are subordinated to the narrative's greater interest in erotic pleasure.
\end{abstract}

Keywords: Skin, Fanny Hill, Disease, Prostitution, John Cleland, Daniel Defoe

The outbreak of plague in Marseille (France's major port) in 1720 galvanised concerns about infectious and communicable disease across eighteenth-century England. The government took swift action in the form of an appeal to the physician Richard Mead. Mead was a 'very eminent physician', ${ }^{1}$ who rose to prominence in 1702 with the publication of his Mechanical Accounts of Poisons, a volume that was highly regarded by

* Email address for correspondence: scro2414@uni.sydney.edu.au

I would like to thank the editors at Medical History and the anonymous reviewers for their thoughtful feedback. My sincerest appreciation goes to Vanessa Smith for her guidance and advice, and to C.B. Johnson for his unwavering support and encouragement.

${ }^{1}$ Abraham Rees, The Cyclopadia or Universal Dictionary of Arts, Sciences, and Literature, Volume XXIII (London: printed for Longman, Hurst, and Rees, 1819), no pagination. 
the scientific community and secured him a place in the Royal Society. ${ }^{2}$ Mead's advice to the government was presented as a treatise entitled A Short Discourse Concerning Pestilential Contagion (1720). The Short Discourse moves between medicine and politics and was, as Emerson Kelly puts it, the 'first book of epidemiological advice produced by a medical practitioner at the request of the state'. ${ }^{3}$ It is comprised of two sections: the first provides descriptions of the plague and puts forward Mead's theory of contagion, while the second gives practical advice for quelling the spread of disease, resulting in the most significant codification of maritime quarantine in England, via the new quarantine Act of 1721 (replacing that of 1710).

The Short Discourse was hugely popular, as evidenced by its many editions (seven within the first year) and translations into multiple different languages (including Russian in the 1770s). In spite of this popularity, Mead attracted critics, who argued that he was ill equipped to offer medical advice on the management of the plague as he had no firsthand knowledge of the disease. He justified himself, however, writing, 'I hope the great resemblance, I have observed between the plague and the smallpox, will justify my writing upon the cure of a disease, which I have never seen'. ${ }^{4}$ Mead does not appear to notice any contradiction between 'observe' and 'have never seen'; indeed, to his mind there wasn't one. This is because the similarity that he 'observes' between the plague and smallpox lies in their common aetiology as communicable diseases, which saw them grouped together under the umbrella of contagionism. Contagionism, which literally translates to 'touching together', is the idea that disease is communicated between infected subjects through physical contact. ${ }^{5}$

Contagionist theory recalibrated the spatial politics of everyday life. For instance, during the 1720 plague outbreak a cordon sanitaire was imposed upon Marseille, and this was heavily policed by both the city militia and the French army. ${ }^{6}$ Medical accounts from inside the city walls reveal both the increasing fear and knowledge the medical professionals experienced as they realised that the disease was communicated through contact. The French physician Anton Deidier was sent to Marseille by Louis XV in 1721 to study the nature of the epidemic. While there, Deidier conducted several experiments on dogs, whereby he lacerated the animals and rubbed bile from recently deceased plague victims into the wounds. After being infected in this manner the dogs exhibited plague symptoms and died. These results were subsequently shared with the medical establishment in England via correspondence with the naturalist and Royal Society fellow John Woodward. ${ }^{7}$ Deidier's initial thoughts were that 'the experiments ... showed ...

\footnotetext{
${ }^{2}$ From the title of this work it is evident that Mead's theory was greatly influenced by Newton's mechanical philosophy, which proposed a particle theory of the body. For a detailed account of Mead's education and status within the medical academy, see Melvin Santer, Confronting Contagion, (Oxford: Oxford University Press, 2015), 142-5.

${ }^{3}$ Emerson Crosby Kelly, Encyclopedia of Medical Sources (Baltimore: Williams \& Wilkins, 1948), 282. Andrew Zuckerman also cites this in his paper on Mead's role in the 1720 quarantine efforts. See Andrew Zuckerman, 'Plague and Contagionism in Eighteenth-Century England: The Role of Richard Mead', Bulletin of the History of Medicine, 78, 2 (Summer, 2004), 274.

${ }^{4}$ This justification was added to later editions of his Short Discourse. Richard Mead, Short Discourse, 8th edition (London: printed by Sam Buckley, 1722), 137-8. This edition is cited by Zuckerman, ibid., 284.

${ }^{5}$ Margaret DeLacy, The Germ of an Idea (Basingstoke and New York: Palgrave, 2016), 1.

${ }^{6}$ Ibid., 148.

${ }^{7}$ For a detailed overview of these experiments, see DeLacy, op. cit. (note 50), 148-51.
} 
beyond doubt that plague can be communicated and is transmissible from one subject to another' ${ }^{8}$ He continues by describing the infectious touch in the following way:

'[By contact I mean] . . . to breath for a long time and very near the burning breath which comes from the mouth of the sick ... to wear the same shirt or sleep in the same bed-clothes . . to touch one's own sores with hands still carrying infected sweat or blood ... The contagion of the plague is something like that of venereal disease'. ${ }^{9}$

Deidier's analogy here, between the plague and venereal disease, is not unlike Mead's likening of the plague to smallpox. That two leading physicians, from opposite sides of the Channel, make use of comparison to better understand the plague themselves and explain it to their contemporaries is significant. It points to the close discursive relationship between the plague and the poxes, one that existed throughout the eighteenth century, everywhere from popular insults to the way that they were pathologised in medical treatises. ${ }^{10}$ Beyond this discursive relationship, these diseases were considered as being a broadly related family of contagious disease, both in that they presented cutaneously and could be transmitted via skin-to-skin contact.

The contagionist framework rendered contact, especially that which is prolonged, intimate or sexual, dangerous. Essentially, the emergence of contagionist theory complicated the innate need to experience the world through touch, as it recast the fundamental, self-defining sense as a potentially self-destructive one. This is seen most clearly through the stigmatisation of sexual touch. Over the seventeenth and eighteenth centuries, fear of venereal infection increased and sexual contact came to be recognised as its primary mode of infection. This, according to Sander L. Gilman, saw the 'the sexualised touch also [become] the sign of death'. ${ }^{11}$

\section{Placing the Blame}

Contagion and communicability were configured along two rival lines of thought during the eighteenth century: inanimate (chemical and mechanical) and animate (animalcules). Mead upheld the former, arguing that contagions were comprised of fumes and vapours that infected the air; however, he also posited that people and goods could imbibe the poison and, in turn, become carriers of the infection. In his words, 'Contagion is propagated by three Causes, the Air; Diseased Persons; and Goods transported from infected Places'. ${ }^{12}$ Though the isolation of these three factors appears to identify the root of the contagion, it also leaves the precise vector of transmission open to conjecture. It was within this gap that Mead ventured explanations that play into eighteenth-century anxieties around class. He wrote, 'It is of more Consequence to be observed, that as Nastiness is a great Source of Infection, so Cleanliness is the greatest Preservative: Which is the true Reason, why the Poor are most obnoxious to Disasters of this Kind' ${ }^{13}$ Class, as well as the national differences and gendered occupations (sailor and prostitute) considered below,

\footnotetext{
${ }^{8}$ Anton Deidier, Traité de la Peste, cited in ibid., 151.

${ }^{9}$ Ibid.

${ }^{10}$ Not only did these comparisons prevail throughout the eighteenth century: they can be traced back to the Renaissance. See ibid., 150-1 and Agnieszka Steczowicz, 'Paradoxical diseases in the late Renaissance: the cases of syphilis and the plague', in George Sebastian Rousseau et al., Framing and Imagining Disease in Cultural History (Basingstoke and New York: Palgrave Macmillan, 2003), 269-84.

${ }^{11}$ Sander L. Gilman, 'Touch, Sexuality and Disease', in W.F. Bynum and Roy Porter (eds), Medicine and the Five Senses (Cambridge: Cambridge University Press, 1993), 202.

12 Richard Mead, A Short Discourse Concerning Pestilential Contagion (London: printed for Sam Buckley in Amen-Corner and Ralph Smith at the Royal Exchange, 1720), 2.

13 Ibid., 48.
} 
constituted a system of social borders that attempted to regulate and order society. The permeating and disruptive nature of disease was, logically, a cause for concern, as it soon became clear that these borders were, in fact, permeable.

Such anxieties were stoked by the prevalence and high visibility of skin disease. David Shuttleton isolates the deaths of Prince Henry and Princess Mary, in 1660, as the trigger for widespread public concern. ${ }^{14}$ Having returned from exile, these otherwise healthy young royals died suddenly from smallpox within months of each other, Henry in September (aged twenty) and Mary in December (aged twenty-nine). Shuttleton writes, '[their deaths] alerted the whole nation to the dangers of what earlier medical texts all describe as a disease of childhood'. ${ }^{15}$ The deaths of Henry and Mary posed two particular problems that the public conversation on contagion and disease mobility attempted to reconcile. The first emerged from their status as 'royal', which should, according to popular belief, have accorded Henry and Mary certain securities. When it transpired that this was not the case, their royal corpses alerted (or perhaps reminded) the public of the indiscriminate nature of disease once it enters a society. Traditionally, smallpox was associated with the lower classes, particularly poor children. ${ }^{16}$ The deaths of Henry and Mary, both adult and royal, belied this notion and ignited panic among the elite. The second problem, which is touched upon in Shuttleton's reference to 'all' earlier medical texts, was that the body is capable of undermining and, in this instance, existing in direct contravention of established medical discourse and consensus. These problems appear to have registered with medical writers involved in the investigation and exposition of contagious diseases. In their attempt to address such problems, medical treatises became imbued with a particular narratological impetus. They began by attempting to uncover and preserve the origin stories of different diseases before shifting their focus to the clarification of symptoms. Whether they were tracing the long history of a disease (by looking to mythical origin sources) or trying to understand contemporary transmission (publishing the stories of recently treated patients), medical writers showed themselves to be deeply invested in pinpointing a precise source, or vector, for diseases circulating in eighteenth-century London. In light of this, the descriptions of cutaneous symptoms that accompany these stories take on the appearance of a key, appended to the main text in order to help readers interpret the skin, or, as Susan Sontag would argue, the 'social text'. ${ }^{17}$

During the eighteenth century, certain mythic origin stories remained in circulation, though they were steadily being replaced with medical theories. The surgeon Daniel Turner provides a significant contribution to this discussion in the form of his 1717 work, Syphilis: A Practical Dissertation on the Venereal Disease. He opens the text with, 'a few Words of its Cause and Origine': ${ }^{18}$ these 'few words' actually take the form of ten detailed origin stories. The first five he dismisses as mere 'whimsical conceipts' ${ }^{19}$ however, their varied

${ }^{14}$ David Shuttleton, 'A culture of disfigurement: imagining smallpox in the long eighteenth century', in George Sebastian Rousseau (ed.), Framing and Imagining Disease in Cultural History (Basingstoke and New York: Palgrave, 2003), 68.

15 Ibid., 68.

${ }^{16}$ Kevin Siena and Jonathan Reinarz (eds), 'Scratching the Surface: An Introduction', A Medical History of Skin (London: Pickering and Chatto, 2013), 8.

17 Susan Sontag, Illness as Metaphor (London: Penguin, 2002), 59.

${ }^{18}$ Daniel Turner, Syphilis: A Practical Dissertation on the Venereal Disease (London: printed for R. Bonwicke, 1717), 1. For a discussion of this text and Turner's treatment of venereal patients see, Philip K. Wilson, 'Exposing the secret disease: recognizing and treating syphilis in Daniel Turner's London', in Linda E. Merians (ed.), The Secret Malady (Lexington, KY: University of Kentucky Press, 1996), 68-84.

${ }^{19}$ Ibid., 2. 
nature introduces a definite thematic scope, within which all disease-origin stories appear to exist. The first two fall within the category of transgressive sex acts: in this case, sex between a leprous male and a menstruating woman, and sodomy with a beast. The last three are somewhat ambiguous - poisoned wine, a 'malevolent star' and a venomous serpent bite ${ }^{20}$ - yet they appear to recall early modern theories, some of which had superstitious or astrological foundations. Turner also cites the idea of disease as moral retribution; in effect, syphilis is represented as corporeal punishment administered on a divine scale. This is so much the case that by the sixth explanation offered, Turner writes, 'on the other hand, it is affirmed to be near as old as the Race of Mankind, and began at the same time with the Sin of Fornication; that it was also known to the Antients' ${ }^{21}$ In his discussion of early modern moralising, Kevin Siena cites the Elizabethan surgeon William Clowes, who argued that the pox was 'a notable testamonie of the just wrath of God'. ${ }^{22}$ Turner's inclusion of these narratives suggests that he inherited Clowes's thinking, if only to a degree.

The remaining four origin tales continue to promote the associations of deviant sex and divine intervention, while also introducing race and class narratives. The first of them attributes the 'cause of the pox' to women's promiscuity. Turner's tone expresses distaste as he describes 'a putrid Ferment, arising from mixt Seeds in the Vagina of a Woman; from which heterogeneous Copula springs the Pocky Venom' ${ }^{23}$ Although it is not explicitly stated, the terms 'mixt seeds' and 'heterogeneous copula' make it likely that this story envisions the prostitute's body as the source of the contagion. Even though Turner predicates this entire opening section on the assurance that he is a detached collator of ideas that are either antiquated or speculative, he appears unable to resist the lure of this classic scapegoat. Relentlessly critical, he adopts the rhetoric of the incensed, unerringly righteous moraliser and transforms the prostitute's genitalia into a petri dish for the growth and multiplication of a 'pocky venom', a substance capable of bringing about the destruction of the gentleman client and, ultimately, his wife and children.

In his historical account of syphilis, Claude Quétel claims that congenital syphilis became 'a problem on a national scale' during the eighteenth century. ${ }^{24}$ This problem is discussed by Bernard Mandeville in his Modest Defence of Public Stews (1724). The Modest Defence was written in response to what Mandeville perceived as the failure of the Society for the Reformation of Manners to successfully curb prostitution in London. While the argument that he makes in this treatise is generally taken to be satirical, I would suggest that it registers genuine concern about the spatial politics of sexuality. Furthermore, it treats sex work in a relatively progressive, albeit humorous, manner. Mandeville dedicates the work to the gentleman of this society, writing, 'it is no small Addition to my Grief to observe, that Your Endeavours to suppress Lewdness, have only serv'd to promote it; and that this Branch of Immorality has grown under Your Hands, as if it was prun'd instead

\section{${ }^{20}$ Ibid., $1-2$.}

21 Ibid., 2.

22 William Clowes, Brief and Necessary Treatise, cited by Kevin Siena in 'The clean and the foul: paupers and the pox in London hospitals, c.1550-c.1700', in Kevin Siena (ed.), Sins of the Flesh (Toronto: Centre for Reformation and Renaissance Studies, 2005), 261.

23 Turner, op. cit. (note 18), 3.

${ }^{24}$ Claude Quétel, The History of Syphilis, Judith Braddock and Brian Pike (trans.) (Baltimore, MD: Johns Hopkins University Press, 1990), 5. Quotation brought to my attention by Barbara J. Dunlap, 'The problem of syphilitic children in eighteenth-century France and England', in Linda E. Merians (ed.), The Secret Malady (Lexington, KY: University of Kentucky Press, 1996), 114. 
of being lopp'd'. ${ }^{25}$ He goes on to propose that the Society's agenda is futile, because lust, desire and 'lewdness' are an inevitable part of the human condition. He argues that not even the most elevated minds (philosophers) were able to go without satisfying this urge: 'But what Wonder if the old Academicks, the Cryenaicks, and Peripateticks, were so lewdly Wanton, when the very Stoicks, who prided themselves in the Conquest of all their other Passions, were forced to submit to this?' ${ }^{26}$ Mandeville does not necessarily view prostitution in and of itself as a vice; however, it becomes a social evil when sexual transactions are mismanaged. Thus, by attempting to 'lop' rather than regulate the trade, the Society exacerbates the situation. He writes,

I hope to be acquitted of my Design, when I have prov'd the following Proposition; That publick Whoring is neither so Criminal in itself, nor so detrimental to the Society as private Whoring; and that the encouraging of publick Whoring, by erecting Stews, will not only prevent most of the ill Consequences of this Vice, but even lessen the Quantity of Whoring in general, and reduce it to the narrowest Bounds which it can possibly be contain'd in. But before we proceed, it is requisite that we examine what those mischievous Effects are which Whoring naturally produces, that we may better judge whether or no they will be prevented by this Scheme.

The greatest Evil that attends this Vice, or could well befal [sic] Mankind, is the Propagation of that infectious Disease, call'd the French-Pox, which in two Centuries, has made such incredible Havock all over Europe. ${ }^{27}$

$[\ldots]$

Our Gentleman of the Army ... are hereby very much weaken'd and enervated; and render'd infit to undergo such Hardships as are necessary for defending and supporting the Honour of their Country: And our Gentry in general seem to distinguish themselves by an ill State of Health, in all Probability the Effect of this pernicious Distemper. .. . But what makes this Mischief the more intolerable is, that the Innocent must suffer by it as well as the Guilty: Men give it to their Wives, Women to their Husbands, or perhaps their Children; they to their Nurses, and the Nurses again to other Children; so that no Age, Sex, or Condition can be entirely safe from the infection. ${ }^{28}$

According to Mandeville, syphilis is an urgent social problem and the biggest risk associated with prostitution. A key part of the disease's impact is that it does not simply affect those involved: it targets 'the innocent', too. This, Mandeville implies, has tragic consequences for the family; however, it is also a troubling thought for the state of the nation. Already at risk from a sickly and ineffective army, England's future was further terrorised an enervated gentry, who marry after living an 'irregular Life ... [and] beget a most wretched, feeble, and sickly Offspring: We can attribute it to nothing else but this, that so many of our ancient Families of Nobles are of late extinct' ${ }^{29}$ This was no idle fear, as there were many high-profile instances of wives becoming infected by their adulterous husbands, the most famous of which was Frances Williams, who was infected by her husband, Charles Hanbury Williams, in $1742 .{ }^{30}$ Such cases confirm Barbara J. Dunlap's theory that if children were victims, they might also survive to generate a 'tainted posterity' of the 'stunted, deformed, and dull - a citizenry that would cause the Enlightenment's vision of human progress to recoil upon itself'. ${ }^{31}$ The syphilitic prostitute, then, was not merely a threat to private life and the individual body: she also posed a threat to the nation.

\footnotetext{
25 Bernard Mandeville, A Modest Defence of Publick Stews (London: printed for T. Read, 1740), iii.

26 Ibid., viii.

27 Ibid., 2.

28 Ibid., 2-3.

${ }^{29}$ Ibid., 4.

${ }^{30}$ For a detailed discussion of this case see, Mary Margaret Stewart, "“And blights with plagues the Marriage hearse": syphilis and wives', in Linda E. Merians (ed.), The Secret Malady (Lexington, KY: University of Kentucky Press, 1996), 106-10.

${ }^{31}$ Dunlap, op. cit. (note 24), 114.
} 
The connection between congenital syphilis and a weakened national body was rendered literal by the gossip that circulated in relation to Queen Anne's many afflictions. Most significant was the monarch's experience of 'defluxion', which was the excessive watering of the eyes and commonly associated with congenital syphilis. ${ }^{32}$ The rumours perpetrated about Queen Anne's health suggest that from the very outset of the century, a macabre vision of a deformed, sickly, sterile body politic haunted the English imagination.

The contamination of gentlemen by prostitutes is a staple of medical literature from the period. In his Treatise on the Venereal Disease (1786), John Hunter writes, 'I was consulted in the following case by the surgeon who attended: July 13th, 1783, a person had connection with a woman of the town: the 30th, that is seventeen days after, a gonorrhoea came on, which was violent'. ${ }^{33}$ In such records, the prostitute's genitals are weaponised, becoming, to quote Kathryn Norberg, 'a biological threat' ${ }^{34}$ Turner similarly represents several cases in which venereal infection, introduced by a prostitute, erodes the line between the street and the home. Of a respectable patient Turner writes, 'His concern was not so much on his own account, but for that of his wife and child. I ask'd him how long it was since he was clap'd; he answered me, nine Years'. ${ }^{35}$ Norberg identifies the years between 1769 and 1802 as the period that seriously aligned venereal disease with the prostitute; however, her research focuses on French literature, and while this assessment holds up well for her readings of Diderot, Prévost and d'Aucour, it is less applicable to their English counterparts. ${ }^{36}$ The English, ever conscious of preserving long-standing class divisions as well as the newer borders of Empire, used venereal disease in order to shore up divides across class and cultural lines from the late seventeenth century onward.

Mead opens part two of A Short Discourse, the section on 'Methods to Prevent Contagion', with the following explication:

As it is a satisfaction to know that the Plague is not a Native of our Country, so this is likewise an Encouragement to the utmost Diligence in finding out the Means to keep ourselves clear from It. This caution consists of two Parts: The preventing its being brought into our Island; And if such a Calamity should happen, The putting a stop to its spreading among $\mathrm{us}^{37}$

The principle aim of Mead's treatise was to serve as a practical guide to the implementation of effective maritime quarantine. Unprecedented attention was granted to maritime quarantine in this period, and the port came to be a notable point of weakness in England's national border. On the one hand the port represented the strength of the nation, both as a maritime power and locus of economic prosperity, yet on the other it created a sense of permeability: ports were sites of weakness, and open borders made England susceptible to disease. The sailor's movement across geographical boundaries became the fundamental destabilising threat to the nation's collective health. The development of England's maritime empire saw, too, the reformation of what had previously been considered clearly demarcated borders. Mead was wrestling with a fading certainty when he described England as 'our Island'. As the outposts of Empire became further scattered,

\footnotetext{
32 Elizabeth Lane Furdell, The Royal Doctors, 1485-1714 (Rochester, NY: University of Rochester Press, 2001), 217.

33 John Hunter, A Treatise on the Venereal Disease, 2nd edition (London: sold by Mr G. Nicol, 1788), 39.

${ }^{34}$ Kathryn Norberg, 'From courtesan to prostitute: mercenary sex and venereal disease, 1730-1802', in Linda E. Merians (ed.), The Secret Malady (Lexington, KY: The University Press of Kentucky), 36.

35 Daniel Turner, Syphilis: A Practical Dissertation on the Venereal Disease, 2nd edition (London: printed for R. Bonwicke, 1724), 98. This case was added to the second edition.

${ }^{36}$ Norberg, op. cit. (note 34), 35.

${ }^{37}$ Mead, op. cit., (note 12), 21.
} 
notions of border solidity had to be relinquished. Travel between coastal boundaries became increasingly frequent, and trade in disease became as common as trade in goods. Mead noticed that disease breaching 'the Island' was often the direct result of trade:

We all know how long a time Perfumes hold their Scent, if wrapt up in proper Coverings: And it is very remarkable, that the strongest of these, like the Matter we are treating of, are mostly Animal Juices, as Mosch, Civet, \&c. and that the Substances found most fit to keep them in, are the very same with those which are most apt to receive and communicate Infection, as Furrs [sic], Feathers, Silk, Hair, Wool, Cotton, Flax, \&c . . ${ }^{38}$

$[\ldots]$

the greatest Danger is from such Goods, as are kept to retain Infection, such as Cotton, Hemp, and Flax, Paper or Books, Silk of all sorts, Linen, Wool, Feathers, Hair, and all kinds of Skins. ${ }^{39}$

The border of 'the Island' itself was also weakened, and ports become a pore upon the nation's body. It was because of this that the sailor was thought to be the root of pox, not merely its conduit, at least within England. ${ }^{40}$ With the sailor occupying this role, the network of transmission can be charted: port (pore), whore, 'respectable' client and wife, with further possible transmission to the infant. Though the prostitute's vagina served as the secondary site of infection, the place the 'pocky venom' went to 'ferment' and multiply, it was the sailor who was considered the source. With these connections in place, the extent of, and motivations for, the persistent characterisation of sailors and whores as perennial carriers, if not pathogens themselves, becomes clearer. Concern over the welfare of the family, coupled with anxiety regarding public health, saw the sailor monitored and exposed by surgeons and novelists alike.

As mentioned above, Mead argued that 'Contagion is propagated by three Causes, the Air; Diseased Persons; and Goods transported from infected Places' ${ }^{41}$ All three of these causes contributed to the popular figuration of sailors as the source of disease. The first (contaminated air) was a significant problem on English ships. In fact, one of Mead's minor projects was the support of Samuel Sutton's system of air pipes. ${ }^{42}$ Sutton's pipes proposed to remedy the noxious air of naval vessels by drawing out the contagious matter through convection. Though ships were not the exclusive source of bad air, the connection between Mead and Sutton would have been enough to impress the image of the contagious and sickly sailor upon the reader's imagination. The navy's culpability is rendered even more sharply by the other two sources: 'diseased persons and imported goods'. Mead's inventory of possible infected goods emphasised the threat posed by the import trade, with a stress laid on textiles, especially those derived from animals. Moreover, Mead advised that the linens explicitly tied to the sailors themselves, especially their bedding, also be subjected to quarantine measures (before even arriving at the port, the sailor's bed was marked as a source of contamination). The sailor becomes a sort of patient $\mathrm{X}$ for all manner of communicable diseases in Mead's work, and this attitude was widely disseminated by medical writers.

\footnotetext{
38 Ibid., 17.

${ }^{39}$ Ibid., 24.

40 This is not to say that the ultimate cause was ascribed to the sailor. The link between disease and the savage other was also pervasive. There are sources that even promote disease as a somewhat necessary evil of expansion and adventure. See William Turnbull, The Naval Surgeon (London: printed for Richard Phillips, 1806), v.

${ }^{41}$ Mead, op. cit., (note 12), 2.

42 For a detailed discussion of this project, see Andrew Zuckerman, 'Disease and Ventilation in the Royal Navy: The Woodenship Years', Eighteenth Century Life, 11 (November, 1987), 77-89.
} 
William Turnbull was one such surgeon, who, in 1786, published An Inquiry Into the Origin and Antiquity of the Lues Venerea. Turnbull provides the following exposé regarding an infected captain.

In the year 1781, a Captain of the Navy (at Portsmouth) being under my care for a large Venereal Ulcer on the glans, accompanied with a considerable discharge from the urethra - his custom was frequently throughout the day, to bathe the parts with warm milk and water, in which he sometimes put a little spirits. A seaman waiting upon him one morning, and being placed in the room where the Captain had been in the evening before, and seeing the glass rummer half full of this mixture (which had been used for the purpose above mentioned) and taking it for rum and milk, drank it off. ${ }^{43}$

Turnbull capitalises on the crude and grotesque and, in this way, reduces the characters in this anecdote to base players. Considering the power dynamics that underpin the relationship between Captain and seaman, a relationship characterised fundamentally by rank, it is unlikely that an inferior would enter their captain's room and presume to drink from his table. Either Turnbull is guilty of embellishment, or this stands out as a peculiarly repulsive inclusion, one that relishes the act of exposure. The sailor is outed as the 'patient zero' in the eighteenth-century project of pox-origin tracing. Furthermore, this story functions as an allegation brought against sailors; it makes the obvious claim that sailors balk at systems of decorum (both respect for rank and table manners) that regulate and keep the public safe and contribute to preserving the nation's health.

Concern about poor hygiene and sordid sexual practices underscored the rules for new seamen. The 1744 edition of these rules was, in fact, motivated entirely by the desire to prevent disease: 'they [new-raised men] should be trained up and instructed in whatever may tend to make them most useful on board his Majesty's ships; to be kept cleanly, in order to prevent sickness; you are therefore hereby required and directed, carefully and punctually to comply with the following rules'. The rules total nine, and four pertain to the cleanliness of the immediate environment (decks, hold and bedding), while another four attempt to regulate the sailor's body itself by way of bathing, exercise, labour and a prohibition on 'fruit and strong liquors'. ${ }^{44}$ The remaining rule states:

You are never to permit any women to be on board, but such as are really the wives of the men they come to; and not to suffer the ship to be too much pestered even with them. But you are to take notice that this indulgence is only tolerated while the ship is in port, and not under sailing orders. ${ }^{45}$

One important aim of this rule was to curtail the spread of pox beyond the port. The structure and purpose of the port lent itself to metaphorical appropriation. ${ }^{46}$ The port became the pore through which the sailor-pathogen could enter and infect the waiting prostitute, who, in her turn, facilitated the infection of the broader population.

\section{Streetwalking}

The rate at which $A$ Short Discourse was republished suggests that it was read by scientific and non-scientific audiences with equal avidity. Such a broad readership gestures to a

\footnotetext{
${ }^{43}$ William Turnbull, An Inquiry Into the Origin and Antiquity of the Lues Venerea; with Observations on its Introduction and Progress in the Islands of the South Seas (London: printed for J. Murray, 1786), xi.

44 John B. Hattendorf et al. (ed.), British Naval Documents 1204-1960 (Aldershot: Scholar Press for the Navy Record Society, 1993), 515-16.

45 Ibid.

${ }^{46}$ Danielle Bobker discusses metaphoric geography in her article 'Sodomy, Geography, and Misdirection in Memoirs of a Woman of Pleasure', University of Toronto Quarterly, 79, 4 (Fall, 2010), 1035-45. Particular reference to nautical metaphor can be found on page 1040 .
} 
cultural investment in quarantine procedure. It is unsurprising that the confluence of fear (sparked by contagion generally and Marseille in particular) and the appeal of managing illness and cure for oneself (evidenced by the spate of medical texts published for lay readers to self-diagnose and self-medicate) saw a text ostensibly written for the state become repurposed for domestic medicine. By this I mean that although A Short Discourse was initially commissioned by the British government for the explicit purpose of rewriting the Quarantine Act, in order to manage maritime borders, it came to be used by Londoners (or at least by London-based novelists) as a model for navigating urban space. The naturalist Richard Bradley (Mead's contemporary) describes the London streetscape in his treatise The Plague at Marseilles Consider'd (1721). He writes,

London at the time of the Plague [of] 1665 was, perhaps, as much crouded with People as I suppose Marseilles to have been when the Plague begun; the Streets of London were in the Time of the Pestilence very Narrow, and, as I am Inform'd, unpaved for the most Part; the Houses by continu'd Jetts one Story above another, made them almost meet at the Garrets, so that the Air within the STREETS was pent up, and had not a due Freedom of Passage, to purifie it self as it ought. ${ }^{47}$

Bradley's London is a heaving, swarming, humid network of streets, the perfect ecosystem for pestilence to fester. It is perhaps unsurprising that Bradley rejected the theory of mechanical poisons (which Mead, by contrast, championed) and instead promoted the living-agent theory of contagion (pioneered by Antonie van Leeuwenhoek). Bradley argued that infectious matter manifested as 'insects' or animalcules. In his words, 'all Pestilential distempers, whether in Animals or Plants, are occasion'd by poisonous Insects convey'd from Place to Place by the Air'. ${ }^{48}$ The concept of infectious animalcules teemed with metaphoric potential and became all the more vivid when the Philosophical Transactions published and endorsed Cosimo Giovanni Bonomo's pioneering work on scabies. Bonomo disseminated the living-agent theory in relation to 'the itch' (scabies), which he describes in the following way:

From this Discovery it may be no difficult matter to give a more Rational account of the Itch, than authors have hitherto delivered us. It being very probable that this contagious Disease owes its origins neither to the melancholy Humour of Galen, nor the corrosive acid of Sylvius, not the particular ferment of Van Helmont, nor the irritating Salts in the Serum or Lympha of the Moderns, but is no other than the continual biting of these Animalcules in the Skin .... ${ }^{49}$

We can draw a parallel between medical descriptions of the animalcule and cultural and fictional representations of idlers and streetwalkers. There are two novels in particular, both experimental in their own way, that speak to this idea. The first is Daniel Defoe's Journal of the Plague Year (1722), which was published just two years after Mead published his short discourse and one year after the plague in Marseille had subsided, and is set during the 1665 plague of London. This time frame suggests that although fears of an imminent outbreak of plague in England had abated, the menace of infection and contagionism was very much present.

If the port was popularly imagined as the nation's pore, then London was its heart, and the city streets were, in turn, seen as its thronging, vibrating arterial network. Defoe's depiction of these streets closely mirrors Bradley's description:

\footnotetext{
${ }^{47}$ Richard Bradley, The Plague at Marseilles Consider'd (London: printed for W. Mears, 1721), 11.

48 Ibid., 57.

49 Richard Mead, 'An Abstract of part of a Letter from Dr Bonomo to Signior Redi, containing some Observations concerning the Worms of Humane Bodies', Philosophical Transaction, 23 (1st of January, 1703), 1297. Although Mead disagreed with the concept of animate contagion in relation to the plague, he recognised the role played by microorganisms in scabies.
} 
Beggars ... swarm in every place about the City, being a great cause of the spreading of the Infection.... It is therefore now ordered, that such Constables ... take special care that no wandring Begger [sic] be suffered in the Streets of this City... ${ }^{50}$

The poor are metamorphosed into a swarming pestilence that overruns the city streets. The living-agent theory emphasised reproductive generation, which casts a shadow over lowerclass reproduction and its contribution to urban crowding. Defoe goes on to describe an incident of transmission in which the infected person is poor, mad and possibly ignorant of his infected state. The scene reads:

A poor unhappy Gentlewoman ... was murther'd [sic] by one of these Creatures in Aldersgate-street. . . He was going along the Street, raving mad to be sure, and singing, the People only said, he was drunk; but he himself said, he had the Plague upon him, which it seems, was true; and meeting this Gentlewoman, he would kiss her; she was terribly frightened as he was only a rude Fellow.... When she see he would overtake her, she turn'd and gave him a Thrust so forcibly, he being weak, and push'd him down backward: But very unhappily, she being so near, he caught hold of her, and pull'd her down also; and getting up first, master'd her, and kiss'd her; and which was worst of all, when he had done, told her he had the Plague, and why should she not have it as well as he. ${ }^{51}$

Defoe envisions the anxieties that epidemics stoke - namely, the fear that social classes and distinctions will be eroded. In this particular episode, the plague recasts the inhabitants of London as potential murderers and murder victims. A 'rude' plague victim who has been driven mad by fever attacks a gentlewoman in the street. The attack is obviously violent; however, Defoe describes it in a way that hints at a sexual undercurrent. The 'Creature' drags down 'the poor unhappy Gentlewoman'; he then kisses her and ultimately infects her. The sexual innuendo that characterises this interaction hints at the slippery line between the plague and pox. When Defoe reveals, in the lines following this passage, that the woman loses her child as a consequence of the assault, this point is reinforced, as disease, as I have previously noted, was not only seen to transgress class boundaries: it was also imagined to compromise national posterity. As this gentlewoman and 'substantial Citizen's Wife' loses her baby, the scene encodes the pervasive idea that contagion weakens the national body. In Defoe's version, the streets of London become infected with the pathogenic poor, who function as vectors of contagious disease and threaten, in some cases deliberately, to infect their social superiors.

Throughout the novel, Defoe discusses the effectualness of quarantine practices in militating against infection. In an earlier scene, he writes,

I was supriz'd, not at the Sight of so many Thieves only, but at the Circumstances I was in; being now to thrust my self in among so many People, who for some Weeks, had been so shye [sic] of my self, that if I met any Body in the Street, I would cross the Way from them. ${ }^{52}$

The Journal's narrator outlines the practice of avoiding crowds during epidemics, enacting Mead's advice: 'For the greater Security herein, it will be advisable to avoid all Crouds [sic] of People'. ${ }^{53}$ Quarantine, as it was codified by Mead, can be said to have reshaped everyday social interactions. The heaving, crowded thoroughfares of London became a space to be managed and policed, in order to avoid the devastating consequences of close bodily contact.

\footnotetext{
${ }^{50}$ Daniel Defoe, A Journal of the Plague Year (London: Penguin, 2003), 45. The discrepancy between beggar and begger occurs in the original. All references to this edition.

${ }^{51}$ Ibid., 154.

52 Ibid., 85.

${ }^{53}$ Mead, op. cit., (note 12), 51.
} 
While Defoe concedes that in principle quarantine is an admirable idea, he does imply that it often fails, because 'infection was propagated insensibly, and by such Persons as were not visibly infected, who neither knew who they infected, or who they were infected by' ${ }^{54}$ Equally possible was the issue of people suppressing their infected status. This occurs in the novel's opening scene, which recounts the condition of the plague's first victims. Defoe emphasises that the victim's family '[endeavour] to conceal as much as possible', ${ }^{55}$ but that their efforts are inevitably betrayed by the symptomatic lesions that mark the corpses:

two Physicians and a Surgeon were ordered to the House, [to] make Inspection. This they did; and finding evident Tokens of the Sickness upon both the Bodies that were dead, they gave their Opinions publickly, that they died of the Plague .... 56

This is a revealing scene as it highlights the way that cutaneous eruptions quite literally rupture the skin, bringing internal disorders to the surface. The 'tokens' ('a spot on the body indicating disease ${ }^{57}$ ) make the status of the infected 'evident' to the physicians and surgeon who examine them. Defoe makes clear that it is not just the victims who are scrutinised: their family is as well. It is the family that has made the effort to conceal the disease, and subsequently it is their efforts that unravel when news of the illness circulates and is made concrete in the weekly Bill of Morality, which Defoe includes: 'Plague 2. Parishes infected 1 $1{ }^{58}$ The two victims thus become the index case for the 1665 London plague, permanently fixed in the parish records. Although these victims are ultimately betrayed by the infection's visibility, the attempt to conceal their status from the healthy exposes the community to risk.

In John Cleland's Memoirs of a Woman of Pleasure (1748), an epistolary novel ostensibly written by the infamous Fanny Hill to a female friend addressed only as 'Madam', streetwalking takes on its full meaning. As Mandeville's theory made clear, it was the possible scope of the prostitute's clientele that underscored much of the period's anxiety towards prostitution. Cleland holds up a mirror to this fear. In her memoirs, Fanny moves problematically between the roles of private mistress and streetwalker and, in so doing, threatens the precarious distinction between the two forms of sex work, as well as class boundaries more broadly. While streetwalking, Fanny picks up a sailor, which completes the network of sexual encounters associated with the spread of venereal disease.

Critics have consistently commented on the absence of disease in the Memoirs and in eighteenth-century erotic fiction more generally. ${ }^{59}$ However, it is important to note the

\footnotetext{
${ }^{54}$ Defoe, op. cit. (note 50), 152.

55 Ibid., 3.

56 Ibid., 4.

57 Ibid., 281.

58 Ibid., 4.

${ }^{59}$ Randolph Trumbach has argued that Fanny Hill maintains the fantasy that 'sex [work] . . . is safe, comfortable and accompanied by love'. He also asserts that Cleland's representation of prostitution differs from the realities of prostitution in the eighteenth century in five ways: 'it is free of drunkenness, it is not associated with crime, it all takes place in safe, indoor environments, and it is a vice, more or less, of the middle and upper ranks of society'. See Randolph Trumbach, 'Modern prostitution and gender in Fanny Hill: libertine and Domesticated fantasy', in G.S. Rousseau and Roy Porter (eds), Sexual Underworlds of the Enlightenment (Chapel Hill, NC: University of North Carolina Press, 1988), 72 and 80. David Weed charges Cleland with 'verbally airbrushing the prostitute's looks and the harsh realities of their working conditions'. See, David Weed, 'Fitting Fanny: Cleland's "Memoirs" and the Politics of Male Pleasure', NOVEL: A Forum on Fiction, 31, 1 (Autumn, 1997), 7. Laura J. Rosenthal goes as far as coining the term 'pornotopia' in order to categorise what she sees as Fanny's 'escape from the usual shifting tides of fortune', especially her apparent escape from venereal infection. See Laura J.
} 
precise aims of the genre, as outlined by James Grantham Turner: 'on the one side [authors of whore biographies] claim to be warning young men against the evils of whoredom, announcing a [...] dissuasive purpose for their pornographia'; on the other they see the role of the artist 'as being not to discriminate against the abject' but to render it 'with extreme aesthetic power'. ${ }^{60}$ While the Memoirs generally resists overt representation of venereal disease, it is not unreasonable to suggest that it is a consistently latent threat, and that this is thrown into sharp relief after Fanny has sex with a sailor.

Many critics have discussed the sailor scene; most often it underscores analyses of suggested homoeroticism in Cleland's writing. ${ }^{61}$ Recent contributions to this dialogue include Annamarie Jagose, who reads the scene as part of the novel's ongoing 'prioritisation of male-female intercourse'. ${ }^{62}$ Meanwhile, Thomas Alan Holmes proposes that the sexual position itself (Fanny and the sailor engage in 'rear-entry' intercourse) 'serves as a compromise between the woman's and man's desires', ${ }^{63}$ which he takes to be the missionary position and anal intercourse respectively. Holmes bolsters his interpretation of the sailor scene by reading it alongside another half-realised instance of sodomy that occurs in the Memoirs. While attending a masquerade, a character named Emily, Fanny's friend and fellow prostitute, is taken to a bagnio. It should be noted that while this assessment works well for Emily, as her partner is duped by her shepherd's

Rosenthal, Infamous Commerce (Ithaca, NY and London: Cornell University Press, 2006), 121-3. On page 121 she states unequivocally that Fanny 'never contracts venereal disease'. Rosenthal's argument is reiterated by Ann Lewis and Markman Ellis in their 'Introduction' to Prostitution and Eighteenth-Century Culture: Sex, Commerce and Morality (London: Pickering \& Chatto, 2012), 10. They claim that Fanny Hill is a 'polite pornotopia' in which 'the prostitute's sex work is clean, safe, healthy and pleasurable'. A notable exception to this trend is Lena Olsson's essay 'Idealized and realistic portrayals of prostitution in John Cleland's Memoirs of a Woman of Pleasure', in Patsy S. Fowler and Alan Jackson (eds), Launching Fanny Hill: Essays on the Novel and its Influences (New York: AMS Press, 2003), 81-101. Olsson critiques the five points raised by Trumbach and offers astute readings of Mrs Brown's brothel, alcoholism, extortion and vulgarity as depicted in the novel. She also points out that the sailor scene is 'potentially the most dangerous'; however, she goes on to conclude that Fanny appears to avoid infection: 98-99.

60 James Grantham Turner, 'The Whores Rhetorick: Narrative, Pornography, and the Origins of the Novel', Studies in Eighteenth-Century Culture, 24 (1995), 301-2.

${ }^{61}$ There is a wealth of interpretation of eighteenth-century sodomy shaming and the role of sodomy within Fanny Hill. Randolph Trumbach's 1977 article 'London's Sodomites: Homosexual Behaviour and Western Culture in the 18th Century' confirms that, in Europe, homosexuality was 'confined to an illicit subculture' and was condemned by the scriptures and because it was deemed unnatural. See Randolph Trumbach, 'London's Sodomites: Homosexual Behaviour and Western Culture in the 18th Century', Journal of Social History, 11, 1 (Autumn, 1977), 3. Trumbach also contributes to the discourse on sodomy shaming in a 1988 essay, op. cit. (note 59), 69-85. Both arguments source evidence from papers produced by the Society for the Reformation of Manners, founded in 1691 to cleanse the streets of 'lewd night-walkers and most detestable sodomites'. Annamarie Jagose's 2007 article "“Critical Extasy”: Orgasm and Sensibility in Memoirs of a Woman of Pleasure' applies Teresa Braunschneider's 2002 work to a reading of Fanny Hill. Jagose posits that Cleland's 'prioritisation of male-female intercourse', Fanny's insistence on linear orgasm and the 'fluid economy' of mutual climax be read within the framework of Teresa Braunschneider's argument that the eighteenth-century, while promoting heteronormative relationships at an institutional level, recognised that 'opposite-gender desire was not taken for granted as natural or inevitable; rather, it emerges as a cultural project that requires tremendous energy to sustain'. See, Annamarie Jagose, “'Critical Extasy”: Orgasm and Sensibility in Memoirs of a Woman of Pleasure', Signs, 32, 2 (Winter, 2007), 461. Jagose cites Teresa Braunschneider, 'Maidenly Amusements: Narrating Female Sexuality in Eighteenth-Century England' (unpublished PhD thesis, University of Michigan, 2002), 14. Danielle Bobker's 2010 article 'Sodomy, Geography, and Misdirection in Memoirs of a Woman of Pleasure' compares Memoirs to Cleland's novel criticism, enabling her to make a compelling case about Cleland's methodology, which is, '[making] . . . bad things look good, then [making] good things look better': 1037.

62 Jagose, ibid., 468.

63 Thomas Alan Holmes, 'Sexual Positions and Sexual Politics: John Cleland's Memoirs of a Woman of Pleasure', South Atlantic Review, 74, 1 (Winter, 2009), 134. 
costume into thinking that hers is a male posterior, implying homosexual preference, Fanny's femininity is unquestioned; the sailor's misdirection is motivated by impatience not homosexual desire. This distinction is an important one as it elucidates a central paradox in the sailor-pathogen metaphor. On the one hand the sailor was a means of rationalising the pervasiveness of an otherwise insidious scourge. However, the navy was emerging as a powerful force that underpinned British nationalism. ${ }^{64}$ So while the image of the individual debauched sailor represented a threat to British borders, through the weakening of national health, the navy holistically signalled the protection and consolidation of borders, in geopolitical terms. It appears that this paradox was appreciated by Cleland, who appropriately exonerates the sailor from sodomy charges but does not quite extricate the figure from his role as vector. In Danielle Bobker's words, the sailor scene 'represents sodomitical desire as a kind of male disorientation that a female pilot can correct' ${ }^{65}$

While most of the contemporary debate on homoeroticism gravitates around the moments in the tavern itself, it is the scenes immediately before and after, coupled with Fanny's subsequent sexual encounters with Mr Norbert and Mr Barville, which illuminate the sailor's pathogenic role most clearly. In their encounter, Cleland's libidinous sailor invokes the same shameless disregard for propriety as Turnbull's thirsty sailor.

I was overtaken by a young sailor. I was then in that spruce, neat, and plain dress which I ever affected, and perhaps might have in my trip a certain air of restlessness unknown to the composure of cooler thoughts. However, he seized me as a prize, and, without ceremony, threw his hands round my neck, and kissed me boisterously and sweetly. I looked at him with a beginning of anger and indignation at his rudeness, that softened away to other sentiments as fast as I viewed him: for he was tall, manly-carriaged, handsome of body and face $\ldots{ }^{66}$

The sailor's paradoxical status is plainly exhibited in Fanny's interpretation of the sailor. $\mathrm{He}$ is dashing and handsome, the model of desirable, heroic and virile masculinity upon which the nation depends. However, he imposes himself upon Fanny, which she, understandably, considers an affront. In so doing he threatens her borders, so that in spite of her begrudging infatuation, the imagery in this scene parallels the broader metaphor of the invasive, perennially contaminating pathogen.

Norberg observes that during this period a distinction was maintained between the 'diseased streetwalker' and the 'elegant courtesan' ${ }^{67}$ It is precisely these categories that Fanny threatens to collapse in the sailor scene. As such, the scene signals an abrupt departure from all the relationships that precede it and alters the relationships that follow. Fanny returns to the milliner's shop after this dalliance and confides the night's adventures to her matronly procuress, Mrs Cole. ${ }^{68}$ Mrs Cole comforts Fanny but also cautions against such behaviour:

But when I got home, and told Mrs Cole my adventure, she represented so strongly to me the nature and dangerous consequences of my folly, the risks to my health in being so open-legged and free of my flesh, that I

${ }^{64}$ For evidence that the navy was an emerging power, see Portsmouth Record Series Portsmouth Dockyard Papers 1774-83: The American War, compiled by R.J.B. Knight, Portsmouth: City of Portsmouth, 1987 and John B. Hattendorf et al. (eds), British Naval Documents 1204-1960. For more on the representation of this emerging power in the novel see, C. Northcote Parkinson, Portsmouth Point (Cambridge, MA: Harvard University Press, 1949).

${ }^{65}$ Bobke, op. cit., (note 61), 468.

66 John Cleland, Memoirs of a Woman of Pleasure (London: Penguin, 2001), 177. All references are to this edition.

${ }^{67}$ Norberg, op. cit. (note 34), 39.

${ }^{68}$ For more on Mrs Cole's role as matron see, Graham Gautier's 'Fanny Hill's Mapping of Sexuality, Female Identity, and Maternity', Studies in English Literature, 1500-1900, 35, 3 (Summer, 1995), 473-91. 
not only took resolutions never to venture so rashly again, which I inviolably preserved, but passed a good many days in continual uneasiness lest I should have met with other reasons, besides the pleasure of that rencounter, to remember it. ${ }^{69}$

This scene explicitly and in detail references venereal infection; moreover, it is worded as a warning (rather than a passing reference to a case or afflicted character), demonstrating the text's interest in representing the threat posed by prostitutes and their connection with the street, sailors and the open port. I would argue that the injunction here directly contradicts a majority of Memoirs readings that argue that Cleland's representation of pleasure ignores the grim realities of prostitution. Mrs Cole's advice is clear and 'strong', so much so it disrupts the novel's erotic, aesthetic surface in favour of alerting the reader to the dangers of indiscriminate sexual encounters.

Tassie Gwilliam's work offers a notable exception to the critical trend of charging Cleland with sanitising sex. Gwilliam identifies Cleland's interest in disease via an insightful reading of the text's fetishisation of maidenheads. This is a pattern throughout the text; however, it plays out most clearly in a sexual episode between Fanny and a client named Mr Norbert. Norbert is a maidenhead hunter who is duped into paying a higher rate for Fanny (whom he is told is a virgin) by Fanny and Mrs Cole. Gwilliam's reading elucidates the connection between the instances of maidenhead hunting in Fanny Hill and the belief in the virgin cure (that sex with a virgin could cure venereal infection). ${ }^{70}$ According to this reading, Cleland includes the narrative of maidenhead hunting in order to represent syphilitic cases. In Gwilliam's words: ‘the prevalence of venereal disease among the prostitutes of London seems to have been accepted as an unavoidable risk; the vigorous exclusion of disease - mentioned but not experienced - in Memoirs of a Woman of Pleasure is so striking that disease can virtually be considered a kind of shadow presence'. ${ }^{71}$ After the sailor episode, however, venereal infection steps out of the shadows to occupy a less peripheral and more graphic position in the text.

After having sex with the sailor, Fanny returns to her relationship with Mr Norbert and then takes up with Mr Barville. The pacing and narrative details that animate these episodes allude to the presence of venereal infection and point to the sailor scene as the source of infection. At the point in the novel when Fanny resumes her relationship with Norbert, Cleland clutters the narrative with a confused description of their relationship. The sense of delay that this evokes is a possible nod to the idea of latency and incubation periods. Fanny's vagina, viewed in light of Turner's ideas, needs time to ferment the pocky venom. Fanny appears to remain entangled with Mr Norbert for 'near a quarter of a year,' during which time she shows him 'proper attendance'. ${ }^{72}$ After a few more sexual encounters, he comes down with a 'high fever which carried him off in four days' time, never once out of a delirium'. ${ }^{73}$ Significantly, Fanny asserts that she is the only woman with whom Mr Norbert is involved and insists that their apparent exclusivity has been

\footnotetext{
${ }^{69}$ Cleland, op. cit. (note 66), 179.

70 Tassie Gwilliam, 'Female Fraud: Counterfeit Maidenheads in the Eighteenth Century, Journal of the History of Sexuality, 6, 4 (April, 1996), 539. Gwilliam draws on research by Antony E. Simpson, 'Vulnerability and the age of female consent: legal innovation and its effect on prosecutions for rape in eighteenth-century London', in G.S. Rousseau and Roy Porter (eds), Sexual Underworlds of the Enlightenment (Chapel Hill, NC: University of North Carolina Press, 1988), 181-205.

${ }^{71}$ Ibid., 540 .

${ }^{72}$ Cleland, op. cit. (note 66), 179.

73 Ibid., 180 .
} 
'of great service to his health'. ${ }^{74}$ Fanny attributes Norbert's untimely demise to excessive consumption of alcohol; however, the emphasis that the text places on fever and delirium hints at symptoms of venereal infection. ${ }^{75}$

The suggestion of venereal disease is even stronger in Fanny's next sexual encounter, with Mr Barville, a dominance and submission enthusiast. The scene is replete with descriptions of marked skin that mimic the lesions associated with syphilis:

In the meantime, I viewed intently the effects of them, which to me at least appeared surprisingly cruel: every lash had skimmed the surface of those white cliffs, which they deeply reddened, and lapping round the side of the furthermost from me, cut, especially into the dimple of it, such livid weals as the blood either spun out from or stood in large drops on; and from some of the cuts I picked out even the splinters of the rod, that had stuck in the skin; nor was this raw work to be wondered at, considering the greenness of the twigs, and the severity of the infliction, whilst the whole surface of his skin was so smooth-stretched over the hard and firm pulp of flesh that filled it as to yield no play or elusive swagging under the stroke, which thereby took place the more plum, and cut into the quick. ${ }^{76}$

If we extend Gwilliam's method of linking Cleland's representation of fetishistic sexual practice with venereal associations, this episode of flagellation may be read as a metaphor for venereal lesions, becoming the moment in which Barville, the gentleman client, becomes the final link in the chain of infection (presumably to carry it back to a wife and family). By delaying the time between Fanny's encounter with the sailor and Barville, the novel works within the temporality established by the theory of fermentation and permits sex with the sailor to be read as the initial clap within this framework of causality. Descriptions of the marks and wounds to Fanny's skin are detailed over two pages. Her 'masses of flesh' are said to 'tingle', 'glow' and be 'coloured red' ${ }^{77}$ while 'that tender part of me, naturally the province of pleasure, not of pain, came in for its share of suffering'. ${ }^{78}$ Fanny's increasingly graphic description, 'you may guess then in what a curious pickle those flesh-cushions of mine were, all sore, raw, and, in fine, terribly clawed off', ${ }^{79}$ aligns with available eighteenth-century descriptions of venereal symptoms. For example, Turner describes venereal lesions as "pretty little sores, full of venomous poison" ${ }^{, 80}$ and also 'rankling', 'festering' sores that cause pain and burning. ${ }^{81}$

Though the leap from lashings to pock marks might seem dissonant to modern readers, the association would have been considerably more immediate to an eighteenth-century audience. This violent imagery and the signs of pox were fused along more literal lines, as public whippings were a punishment administered against venereal patients. The practice is discussed in Edmund Curll's notorious Uses of Flogging in Venereal Affairs (1718), and it was enforced by London hospitals, such as St Thomas's. ${ }^{82}$ The whippings occurred after the initial 'clap' was deemed cured, with the intent of ensuring the skin remained marked, thereby achieving the double intent of alerting the public to the patient's status and dissuading the patient from further lewd conduct. ${ }^{83}$ The whipping to which Fanny

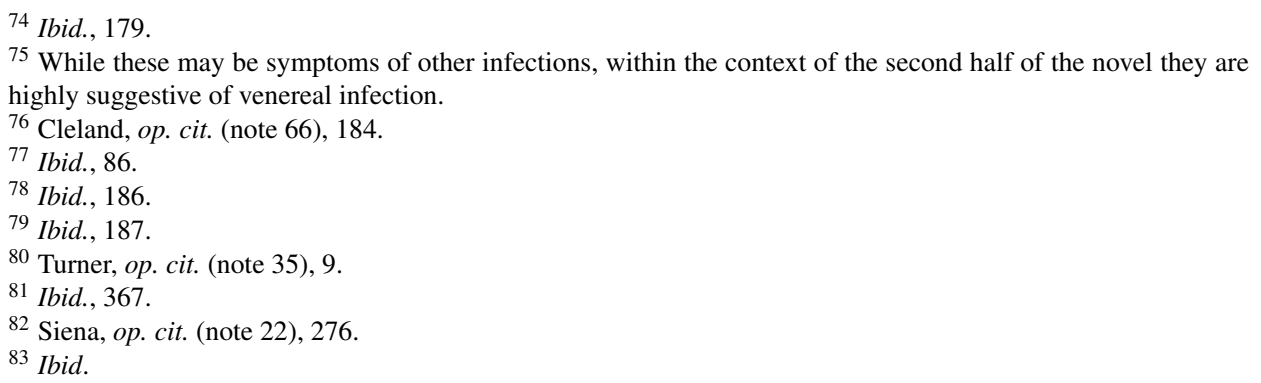


is subject marks her skin with venereal-like lesions that are suggestive of infection. While this may not constitute a clear-cut symptom, it does point to the novel's interest in exploiting an available litany of symptoms (fever, delirium, weal) so that the knowing reader is able to interpret Fanny's body and the dangers attendant on indiscriminate sexual encounters. Moreover, the allusion to the punitive measure of flogging is indicative of the novel's interventionist function and the promotion of domestic relationships over promiscuous ones. Though the pornographic episodes provide the reader with arousal, the narrative ultimately sees Fanny reformed through marriage with her first true love Charles and, as such, the pornographic is dissolved into a conventional marriage plot.

In 1712, George Granville published a poem entitled 'Cleora', which tells the story of a young woman who satisfies her ambition of wedding a peer, though he is old and lecherous. He inevitably infects her with a venereal disease, which he catches from a prostitute. In the words of the poem:

\footnotetext{
A brutal sot, who, while she holds his head,

With drunken filth bedaubs the nuptial bed:

$[\ldots]$

What then may be the chance that next ensues?

Some vile disease fresh reeking from the stews:

The secret venom, circling in her veins,

Works thro' her skin, and bursts in bloating stains:

Her cheeks their freshness lose and wonted grace,

And an unusual paleness spreads her face:

$[\ldots]$

Scarce with her life she 'scapes, expos'd to shame,

In body tortur'd, murder'd in her fame,

Rots with a vile adulteress's name;

Abandon'd by her friends, without defence,

And happy only in her innocence.
}

Granville's poem renders with absolute clarity the anxieties surrounding sexual touch in eighteenth-century England. The relationships between prostitutes and their married clientele were regarded as a dangerous erosion of the line between the street and the home, and their presence was widely believed to impregnate the domestic sphere with 'vile disease'. This poem reifies the concerns present throughout Cleland's Memoirs and also upsets the solution of marriage that Memoirs proposes. While Fanny is ostensibly reformed by marriage, the shadow of her sexual history - namely, her time as a street walker - represents a threat to her new domestic circumstances. The network of her relationships in the latter half of the novel gestures to the potential contamination of her husband and progeny, too. However, Granville goes further than Cleland. Rather than marking the body of the socially inferior prostitute with 'tokens' of disease or glowing redness, Granville actually shows the reader the infected wife, emphasising her 'shame' and tragic 'innocence'. Granville articulates what Mandeville and Cleland tacitly express - that is, that indiscriminate sexual touch endangers domestic life and, by extension, the nation's future.

The women imagined by Defoe, Cleland and Granville remind us that skin is a textual phenomenon that requires us to be alert to both tactile and visual cues. Defoe and Cleland's writings, in particular, serve not just as passive cautionary tales but as actively interventionist texts. Peter Wagner's work has shown that eighteenth-century readers 
sometimes repurposed medical texts for erotic pleasure; close reading of the Memoirs suggests that the opposite is also true. ${ }^{84}$ That is to say, Cleland, who is (rather infamously) regarded as the first author of a pornographic novel, was experimenting with the genre in order to alert the reader to the dangers of London streetwalking, for both the client and prostitute. He also expresses an urgent deterrence against this type of sex. Reading, Cleland implies, is a preventative measure, one that inures the body against dangerous contagion.

${ }^{84}$ Peter Wagner, 'The discourse on sex - or sex as discourse: eighteenth-century medical and paramedical erotica', in Roy Porter and G.S. Rousseau (eds), Sexual Underworlds in the English Enlightenment (Chapel Hill, NC: University of North Carolina Press, 1988), 46-68. 